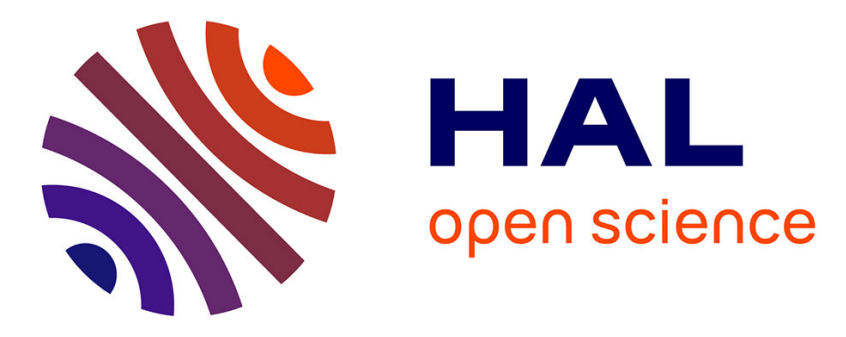

\title{
Rickettsia massiliae infection after a tick bite on the eyelid
}

Carole Eldin, Giulio Virgili, Luciano Attard, Sophie Edouard, Pierluigi Viale, Didier Raoult, Philippe Parola

\section{> To cite this version:}

Carole Eldin, Giulio Virgili, Luciano Attard, Sophie Edouard, Pierluigi Viale, et al.. Rickettsia massiliae infection after a tick bite on the eyelid. Travel Medicine and Infectious Disease, 2018, 26, pp.66-68. 10.1016/j.tmaid.2018.08.002 . hal-01970219

\section{HAL Id: hal-01970219 https://hal.science/hal-01970219}

Submitted on 11 Apr 2019

HAL is a multi-disciplinary open access archive for the deposit and dissemination of scientific research documents, whether they are published or not. The documents may come from teaching and research institutions in France or abroad, or from public or private research centers.
L'archive ouverte pluridisciplinaire HAL, est destinée au dépôt et à la diffusion de documents scientifiques de niveau recherche, publiés ou non, émanant des établissements d'enseignement et de recherche français ou étrangers, des laboratoires publics ou privés. 


\section{Rickettsia massiliae infection after a tick bite on the eyelid}

Dear Editor, we read with interest the paper [1] describing diverse rickettsial infections in Croatia and would like to describe a case of Rickettsia massiliae infection and highlight previously reported cases of this unusual infection.

A 61-year-old woman, was bitten by a tick on her right eyelid while walking in a wooded area a few kilometres from Bologna, Italy. She removed the tick the day after the bite and after four days she developed an erythematous lesion on her right eyelid and latero-cervical satellite lymphadenopathy. She also developed occipital headache with painful neck, low grade fever, general malaise, asthenia and generalized joint pain. She was examined by a general practitioner and an ophthalmologist. Amoxicillin/clavulanate $875 / 125 \mathrm{mg}$ q12h and ofloxacin eye drops therapy was started, with no benefit.

Because of the persistence of symptoms, she went to the A\&E department of Sant'Orsola-Malpighi Hospital in Bologna. Blood examinations, brain CT scan and chest X-ray were normal. Doxycycline was started and the dosing interval of amoxicilline/clavulanate was increased for a total duration of 15 and 21 days respectively. She had fever, occipital headaches, severe asthenia, low-grade hip and knees arthralgia for an additional 4-5 days, with progressive clinical resolution. At the last clinical visit, the patient's overall condition was good: she had a complete resolution of symptoms except mild asthenia.

Biopsy and swab of the eyelid lesion were sent to the reference center for rickettsial diseseases in Marseille, France. DNA was extracted from skin biopsy and swab using the EZ1 Advanced XL (Qiagen, German) biorobot and the DNA tissue kit. In-house specific real-time qPCR targeting all the spotted fever group Rickettsia, and 3 qPCR specifically targeting $R$. conorii, $R$. mongolitimonae and $R$. massiliae were performed using primers and probes previously described [2]. The qPCRs for the spotted fever Rickettsia group and $R$. massiliae were positive with $\mathrm{Ct}$ value at 33 and 27 respectively. Specific qPCR for $R$. conorii and $R$. mongolitimonae were negative. qPCR was positive for $R$. massiliae with $37 \mathrm{Ct}$ value on the swab sample.
R. massiliae was first isolated in 1990 in a tick (Rhipicephalus turanicus) in southern France and described in 1993 as a new spotted fever group Rickettsia [3]. Then, it has been found in Rhipicephalus spp ticks in Europe, Africa and America [4,5]. It is a good example of a bacteria identified in ticks several years before its involvement in human diseases.

To date, eight human cases of $R$. massiliae infection have been reported (Table 1). In 2006, Vitale et al. [6] obtained the first human isolate from a patient presenting with spotted fever. Almost all cases have been reported from the Mediterranean region, except one in a Spanish traveler returning from Argentina (Table 1). Clinical presentation is mostly the one of a spotted fever rickettsiosis with eschar inoculation, fever and rash, that can be purpuric [7]. However, one case of SENLAT (Scalp Eschar and Neck Lymphadenopathy After Tick bite) has also been reported (Table 1). In our present case, the clinical presentation is close to that of a SENLAT, but with an atypical eschar site in the eyelid, mimicking Meibomian cyst. It adds new data about the clinical manifestations of $R$. massiliae infection. This observation is in line with previous studies suggesting that SENLAT is not a pathogenspecific reaction [8].

qPCR on a cutaneous swab specimen of the eschar detected $R$. massiliae. The use of swab for the diagnosis of rickettsia is less invasive, especially in atypical localization where cutaneous biopsy can be difficult [9]. In our case, both the biopsy sample and swab sample were positive, again demonstrating that the swab sampling is a sensitive technique.

To date, no case of $R$. massiliae infection had a fatal outcome. $R$. massiliae, similarly to Rickettsia aeschlimannii, has a natural resistance to rifampicin, which is associated with a different $r p o B$ sequence than other rickettsiae [6]. The therapeutic strategy is the same as recommended for all tick-borne rickettsioses [9]: prompt doxycycline treatment should be initiated in case of clinical suspicion. 


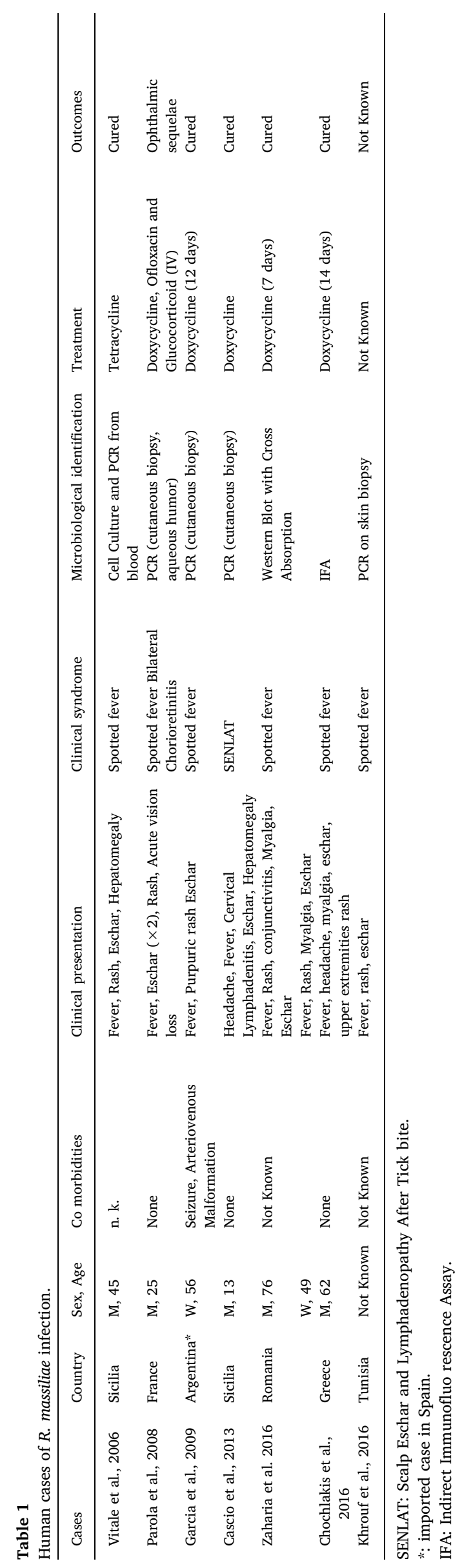




\section{References}

[1] Dzelalija B, Punda-Polic V, Medic A, Dobec M. Rickettsiae and rickettsial diseases in Croatia: implications for travel medicine. Trav Med Infect Dis 2016;14:436-43. https://doi.org/10.1016/j.tmaid.2016.06.010.

[2] Renvoisé A, Rolain J-M, Socolovschi C, Raoult D. Widespread use of real-time PCR for rickettsial diagnosis. FEMS Immunol Med Microbiol 2012;64:126-9. https://doi. org/10.1111/j.1574-695X.2011.00899.x.

[3] Beati L, Raoult D. Rickettsia massiliae sp. nov., a new spotted fever group Rickettsia. Int J Syst Bacteriol 1993;43:839-40. https://doi.org/10.1099/00207713-43-4-839.

[4] Blanda V, Torina A, La Russa F, D'Agostino R, Randazzo K, Scimeca S, et al. A retrospective study of the characterization of Rickettsia species in ticks collected from humans. Ticks Tick-Borne Dis 2017;8:610-4. https://doi.org/10.1016/j.ttbdis.2017. 04.005.

[5] Matsumoto K, Ogawa M, Brouqui P, Raoult D, Parola P. Transmission of Rickettsia massiliae in the tick, Rhipicephalus turanicus. Med Vet Entomol 2005;19:263-70. https://doi.org/10.1111/j.1365-2915.2005.00569.x.

[6] Vitale G, Mansuelo S, Rolain J-M, Raoult D. Rickettsia massiliae human isolation. Emerg Infect Dis 2006;12:174-5. https://doi.org/10.3201/eid1201.050850.

[7] García-García JC, Portillo A, Núñez MJ, Santibáñez S, Castro B, Oteo JA. A patient from Argentina infected with Rickettsia massiliae. Am J Trop Med Hyg 2010;82:691-2. https://doi.org/10.4269/ajtmh.2010.09-0662.

[8] Dubourg G, Socolovschi C, Del Giudice P, Fournier PE, Raoult D. Scalp eschar and neck lymphadenopathy after tick bite: an emerging syndrome with multiple causes. Eur J Clin Microbiol Infect Dis Off Publ Eur Soc Clin Microbiol 2014;33:1449-56. https://doi.org/10.1007/s10096-014-2090-2.

[9] Delord M, Socolovschi C, Parola P. Rickettsioses and Q fever in travelers (20042013). Trav Med Infect Dis 2014;12:443-58. https://doi.org/10.1016/j.tmaid.2014. 08.006 .
Aix Marseille Univ, IRD, AP-HM, SSA, VITROME, IHU-Méditerranée Infection, Marseille, France

Giulio Virgili ${ }^{1}$, Luciano Attard

Infectious Disease Unit S. Orsola-Malpighi Hospital Alma Mater Studiorum University of Bologna, Italy

Sophie Edouard

Aix Marseille Univ, IRD, AP-HM, MEPHI, IHU-Méditerranée Infection, Marseille, France

Pierluigi Viale

Infectious Disease Unit S. Orsola-Malpighi Hospital Alma Mater Studiorum University of Bologna, Italy

Didier Raoult Aix Marseille Univ, IRD, AP-HM, MEPHI, IHU-Méditerranée Infection, Marseille, France

Philippe Parola Aix Marseille Univ, IRD, AP-HM, SSA, VITROME, IHU-Méditerranée Infection, Marseille, France E-mail address: carole.eldin@gmail.com (C. Eldin)

\footnotetext{
* Corresponding author. VITROME, Institut Hospitalo-Universitaire Méditerranée Infection, 19-21 boulevard Jean Moulin, 13005, Marseille, France.

${ }^{1}$ These authors contributed equally to the work and should be considered as first Co-authors.
} 